pathways of molecular species of lecithin by rat lung slices. Biochim. Biophys. Acta, 248: 274 (1971).

3. Arvidson, G. A. E.: Structural and metabolic heterogeneity of rat liver glycerophosphatides. Eur. J. Biochem, 4: 478 (1968).

4. Bartlett, G. R.: Phosphorus assay in column chromatography. J. Biol. Chem., 234: 466 (1959).

5. Brumley, G. W., Cernick, V., Hodson, W. A., Normand, C., Fenner, A., and Avery, M. E.: Correlations of mechanical stability, morphology, pulmonary surfactant, and phospholipid content in the developing lamb lung. J. Clin. Invest., 46: 863 (1967).

6. Clements, J. A., Nellenbogen, J., and Trahan, H. J.: Pulmonary surfactant and evolution of the lungs. Science, 169: 603 (1970).

7. Erbland, J. F., and Marinetti, G. V.: The enzymatic acylation and hydrolysis of lysolecithin. Biochim. Biophys. Acta, 105: 128 (1965).

8. Folch, J., Leeds, M., and Sloane-Stanley, G. H.: A simple method for the isolation and purification of total lipids from animal tissues. J. Biol. Chem., 226: 497 (1957).

9. Frosolono, M. F., Charms, B. L., Pawlowski, R., and Slivka, S.: Isolation, characterization and surface chemistry of a surfaceactive fraction from dog lung. J. Lipid Res., 11: 439 (1970).

10. Frosolono, M. F., Slivka, S., and Charms, B. L.: Acyl transferase activities in dog lung microsomes. J. Lipid Res., 12: 96 (1971).

11. Gluck, L., Kulovich, M. F., Eidelman, H. I., Cordero, L., and Khazin, A. F.: Biochemical development of surface activity in mammalian lung. IV. Pulmonary lecithin systhesis in the human fetus and newborn and etiology of the respiratory distress syndrome. Pediat. Res., 6: 81 (1972).

12. Gluck, L., Landowne, R. A., and Kulovich, M. V.: Biochemical development of surface activity in mammalian lung. III. Structural changes in lung lecithin during development of rabbit fetus and newborn. Pediat. Res., 4: 352 (1970).

13. Gluck, L., Sribney, M., and Kulovich, M. V.: The biochemical development of surface activity in mammalian lung. II. The biosynthesis of phospholipids in the lung of the developing rabbit fetus and newborn. Pediat. Res., 1: 247 (1967).

14. Hill, E. E., and Lands, W. E. M.: Phospholipid metabolism. In: S. J. Wakil: Lipid Metabolism, Ed. 1, p. 185 (Academic Press, New
York, 1970).

15. Kennedy, E. P., and Weiss, S. B.: The function of cytidine coenzymes in the biosynthesis of phospholipides. J. Biol. Chem., 222: 193 (1953).

16. Kikkawa, Y., Motoyama, E. K., and Gluck, L.: Study of the lungs of fetal and newborn rabbits: morphologic, biochemical and surface physical development. Amer. J. Pathol., 52: 177 (1968).

17. Mason, R. J., Huber, G., and Vaughan, M.: Synthesis of dipalmitoyl lecithin by alveolar macrophages. J. Clin. Invest., 51: 68 (1972)

18. Morgan, T. E., and Edmunds, L. H., Jr.: Pulmonary artery occlusion. III. Biochemical alterations. J. Appl. Physiol., 22: 1012 (1967).

19. Morgan, T. E., Finley, T. N., Huber, G. L., and Fialkow, H.: Alterations in pulmonary surface active lipids during exposure to increased oxygen tension. J. Clin. Invest., 44: 1737 (1965).

20. Ohta, M., Hasegawa, H., and Ohmo, K.: Calcium independent phospholipase $A_{2}$ activity in rat lung supernatant. Biochim. Biophys. Acta, 280: 552 (1972).

21. Renkonen, O., Gahmeberg, C. G., Simons, K., and Kääriäinen, L.: The lipis of the plasma membranes and endoplasmic reticulum from cultured baby hamster kidney cells (BHK 21). Biochim. Biophys. Acta, 255: 65 (1972).

22. Arthur H. Thomas Co., Philadelphia, Pa.

23. Armour Pharmaceutical Co., Chicago, III.

24. DC-Fertig Platten Kieselgel $60 \mathrm{~F}_{254}$, E. Merck, Darmstadt, Germany.

25. Amersham, England.

26. Frankfurt/Main, Germany.

27. Calbiochem, Los Angeles, Calif.

28. Boehringer and Soehne G.m.b.H., Mannheim, Germany.

29. We thank Miss Ritva Metsola for excellent technical assistance and professor Ossi Renkonen, Ph.D., for helpful discussions.

30. This work was supported by the Foundation for Pediatric Research in Finland.

31. Requests for reprints should be addressed to: K. O. Raivio, M.D., Childrens Hospital, University of Helsinki, Stenbäckinkatu 11 SF-00290 Helsinki 29, Finland.

32. Accepted for publication July 5, 1974 .

Printed in U.S.A.

\title{
Total Body Potassium Estimations in Young Children: The Interpretation of Results
}

\author{
M. D. MANN, M. D. BOWIE, (34) AND J. D. L. HANSEN \\ Department of Paediatrics and Child Health, University of Cape Town and Red Cross War Memorial \\ Children's Hospital, Rondebosch, Cape, South Africa
}

\section{Extract}

The whole body counter has provided a fast and accurate method of determining the total body potassium (TBK) of an individual. The interpretation of a single determination does present difficulties because of individual differences in body composition. The normal range, expressed in milliequivalents per kilogram, is so wide that an individual can lose $33 \%$ of his TBK and the result be interpreted as normal. To overcome this problem the prediction of the normal TBK of an individual from functions of weight (W), height (H), and skinfold thickness has been investigated and the accuracy of prediction of TBK and $\log$ TBK by various functions of weight, height, and skinfold thickness compared. Eighty-seven children aged 1.5-27 months and of varying height and weight for age were studied. None had any abnormality which may have resulted in potassium depletion at the time of study. The best prediction of TBK (in milliequivalents or milliequivalents per kilogram) by functions of weight and or height $f(W, H)$ had $95 \%$ tolerance limits of $100 \% \pm 18.2 \%$. Using a function of the 
$\log$ transformation of mean skinfold thickness including a $f(W, H)$ narrowed the tolerance limits to $\pm 6 \%$. The best prediction of the log TBK (in milliequivalents or milliequivalents per kilogram) by $\mathbf{f}(\mathbf{W}, \mathbf{H})$ gave tolerance limits of $\pm 3.3 \%-4.8 \%$. The best prediction of the $\log$ TBK in milliequivalents was $f(W, H)$ and $\log$ transformation of mean skinfold thickness which gave narrow $95 \%$ tolerance limits of 100 $\pm 1.3 \%$.

\section{Speculation}

In nonedematous children a function of $(W / H)^{1 / 4}, W / H^{2}$, and $\log$ transformation of skinfold thickness is an accurate predictor of the $\log$ TBK in milliequivalents. The narrow $95 \%$ tolerance limits allow the detection of small deviations from normal. The measurement of skinfold thickness is inaccurate in edematous patients and the TBK has to be predicted from $\mathrm{f}(\mathrm{W}, \mathrm{H})$ alone. The tolerance limits for the prediction of $\log$ TBK in milliequivalents by $(W / H)^{1 / 4}$ and $W / H^{2}$ are still narrow. The accurate prediction of the normal TBK of an individual by simple anthropologic measurements enhances the clinical value of TBK determinations. Relatively small deviations from normal can be detected in edematous and nonedematous children.

Potassium depletion occurs in a variety of clinical states and results in many disturbances of structure and function. Serum potassium concentrations, balance studies, analysis of biopsy material, and exchangeable potassium measurements are either unrelated to the intracellular concentration or are so time consuming that a diagnosis of potassium depletion can only be made in retrospect. The whole body counter has provided a fast and accurate method of determining the TBK of an individual. The interpretation of a single determination does present difficulties because of individual differences in body composition, particularly body fat. The normal range, expressed in milliequivalents per kilogram, is so wide that an individual can lose $33 \%$ of his TBK and the result interpreted as normal.

To overcome this problem, the prediction of the normal TBK of an individual from functions of weight, height, and skinfold thickness has been investigated. A function of skinfold thickness and weight as a percentage of the expected weight for height has been described (19). This paper compares the accuracy of the prediction of TBK and log TBK by this and other functions of weight, height, and skinfold thickness.

\section{CLINICAL MATERIAL}

The ideal method for predicting TBK should be applicable to all children ranging from the underweight to the obese. The inclusion of underweight children is of particular importance as they are prone to diseases (e.g., diarrhea) where potassium depletion is often of significance.

Eighty-seven children were selected for investigation, none of whom had any abnormality which may have resulted in potassium depletion at the time of study. The children weighed between 2.7 and $10.9 \mathrm{~kg}$ and had a supine length of $47.5-76.0 \mathrm{~cm}$. Their weights ranged from 45 to $125 \%$ of the expected weight for age (16). Fifty were less than $80 \%$ of the expected weight for age, and of these 12 were below $60 \%$. The children can be divided into three groups. Group 1 was comprised of 30 normal children aged 1.5-12 months attending a Child Welfare Clinic (well baby clinic). Group 2 was comprised of 16 children aged 1.5-12 months convalescent in hospital after a variety of acute illnesses. Group 3 consisted of 41 children aged 5-27 months convalescent after admission to hospital with kwashiorkor.

Groups 2 and 3 were mostly the underweight children in the series and at the time of study would have been classified by Waterlow (29) as growth retarded but not malnourished or by Monckeberg (21) as nutritional dwarfs. Intracellular potassium concentration returns rapidly to normal after starting treatment $(3,14,30)$ and our patients had shown no signs of illness and had serum albumin concentrations greater than $3 \mathrm{~g} / 100 \mathrm{ml}$ for at least 2 weeks before investigation.

\section{METHODS}

Total body potassium was measured with a Packard model 5107 whole body counter with maximum error of $\pm 5 \%$ (12, 17, 18).

Nude weight and supine crown to heel length were recorded immediately after each TBK determination. Skinfold thickness was measured with Harpenden skinfold calipers on the lefthand side. When the midtriceps and subscapular skinfold thicknesses were measured the children were sitting with the arm abducted $90^{\circ}$, the elbow flexed $90^{\circ}$, and the hand pronated. The midtriceps skinfold thickness was measured at a point halfway between the posterior tip of the acromion and the olecranon. The subscapular skinfold thickness was measured $2.5 \mathrm{~cm}$ inferior and medial to the inferior angle of the scapula. The paraumbilical skinfold thickness was measured $2.5 \mathrm{~cm}$ lateral to the umbilicus with the child supine.

The skinfold thickness at a particular site was the mean of five measurements. The measurements in these positions were more reproducible than in the standard positions (9). When the skinfold thickness was between 4 and $7 \mathrm{~mm}$, the coefficient of variation was approximately $2 \%$. At either extreme, i.e., skinfold thickness of 3 and $12 \mathrm{~mm}$, it was approximately $5 \%$.

Measurements of the midthigh and iliac crest skinfold thicknesses were not reproducible, probably because of difficulties in determining the exact site of measurement from anatomical landmarks. They were not used in the derivation of any function for the prediction of TBK.

Many functions of $\mathrm{W}, \mathrm{H}$, and $\mathrm{W} / \mathrm{H}$ have been used as predictors of TBK, as correction factors for self-absorption in whole body counting, or as ponderal indices $(6-8,15,28)$. The following functions were investigated: $W^{1 / 4}, W^{1 / 2}, W^{3 / 4}$, $\mathrm{W}, \mathrm{W}^{3 / 2}, \mathrm{~W}^{2}$, and $\mathrm{W}^{3}, \mathrm{H}^{1 / 4}, \mathrm{H}^{1 / 2}, \mathrm{H}^{3 / 4}, \mathrm{H}, \mathrm{H}^{3 / 2}, \mathrm{H}^{2}, \mathrm{H}^{3}$, $\mathrm{W} / \mathrm{H}, \mathrm{W}^{2} / \mathrm{H}, \mathrm{W}^{3} / \mathrm{H}, \mathrm{W} / \mathrm{H}^{2}, \mathrm{~W} / \mathrm{H}^{3}, \mathrm{~W}^{3} / \mathrm{H}^{2}, \mathrm{~W}^{2} / \mathrm{H}^{3},(\mathrm{~W} / \mathrm{H})^{1 / 4}$, $(\mathrm{W} / \mathrm{H})^{1 / 2},(\mathrm{~W} / \mathrm{H})^{2}$, and $(\mathrm{W} / \mathrm{H})^{3}$.

In addition, the use of the midtriceps, paraumbilical, and subscapular skinfold thickness was studied.

It was assumed that there was a linear relationship between the TBK or log TBK (in millequivalents or milliequivalents per kilogram) and the predicting function.

The regression of TBK or $\log$ TBK on each of the functions was calculated; i.e., on each variable singly, on every pair, on every triplet, and on all possible combinations of four of the variables. The best predictors in each set were selected, using $r$ in the case of single variables and $\mathrm{R}^{2}$ when there were two or more variables. The significance of each variable in these regressions was checked by calculating the additional reduction in the sum of squares. The reduction due to the inclusion of the fourth independent variable was not significant and this set was excluded from further analysis $(20,27)$.

The predicted TBK or log TBK was calculated for each child using the equations for the regression surfaces which gave the best fit. Two methods may be used for comparing the observed and predicted TBK values.

\section{METHOD 1}

The difference between the two values gives an indication of the absolute deviation from normal, but not of its importance; e.g., the importance of a deviation of $50 \mathrm{mEq}$ is not the same when the predicted value is $250 \mathrm{mEq}$ and when it is $500 \mathrm{mEq}$. A more serious disadvantage is the difficulty in calculating the 
normal range for each case. This is not great when the log transformation of the corrected skinfold thickness or a single $\mathrm{f}(\mathrm{W}, \mathrm{H})$ is used as the predictor, but becomes greater for each additional variable. It also becomes more difficult to construct meaningful tolerance limits.

\section{METHOD 2}

An indication of the magnitude of the deviation is obtained when the observed value is expressed as a percentage of the predicted value. The tolerance limits remain the same for every case. This method of expression has been used in this paper to facilitate comparison of the functions investigated as single and multivariate predictors of TBK. The observed TBK has been expressed as a percentage of the value predicted from the regression plane. The $95 \%$ tolerance limits were calculated for this ratio, i.e., observed $\mathrm{TBK}$ in milliequivalents as a percentage of the predicted TBK in milliequivalents or the $\log _{10}$ of the observed TBK in milliequivalents as a percentage of the predicted $\log _{10}$ TBK in milliequivalents. This method of expression gives results which are very similar to the conventional tolerance limits at the mean values of the $f(W, H)$ (20).

\section{RESULTS}

\section{TBK IN MILLIEQUIVALENTS PER KILOGRAM AND} PER CENTIMETER

The mean TBK values of the children, expressed in milliequivalents per kilogram and per centimeter are given in Table 1, with the SD and $95 \%$ tolerance limits. The range of values obtained is wide in both methods of expression.

PREDICTION OF TBK IN MILLIEQUIVALENTS AND MILLIEQUIVALENTS PER KILOGRAM BY FUNCTION OF W, H, AND W/H

The best single predictor of TBK in milliequivalents was weight and of TBK in milliequivalents per kilogram, $\mathrm{W} / \mathrm{H}^{2}$. The $95 \%$ tolerance limits $100 \% \pm 18.4 \%$, for the prediction of TBK in milliequivalents per kilogram are slightly narrower than those for TBK in milliequivalents (Table 2). When two $\mathrm{f}(\mathrm{W}, \mathrm{H})$ were used, the best prediction of TBK in milliequivalents was given by $\mathrm{W}^{3 / 4}$ and $\mathrm{W}^{2} / \mathrm{H}^{3}$ and of $\mathrm{TBK}$ in milliequivalents per kilogram by $(\mathrm{W} / \mathrm{H})^{3}$ and $\mathrm{W}^{2} / \mathrm{H}^{3}$. The tolerance limits for the latter prediction, $100 \% \pm 18.2 \%$, are only very slightly narrower than those for TBK in milliequivalents by two $\mathrm{f}(\mathrm{W} / \mathrm{H})$ and single variable prediction of TBK in milliequivalents per kilogram (Table 2).

PREDICTION OF TBK IN MILLIEQUIVALENTS PER KILOGRAM BY FUNCTIONS OF SKINFOLD THICKNESS

A logarithmic transformation of the individual skinfold thicknesses gave a better prediction of the TBK in milliequivalents per kilogram than any of the functions of weight and height investigated. The prediction was improved by using the mean skinfold thickness (Table 3 ). The $\log$ transformation was

Table 1. Mean, SD, and 95\% tolerance limits for total body potassium (TBK) in milliequivalents per kilogram and per centimeter

\begin{tabular}{lcc} 
& \multicolumn{2}{c}{ TBK } \\
\cline { 2 - 3 } & $\mathrm{mEq} / \mathrm{kg}$ & $\mathrm{mEq} / \mathrm{cm}$ \\
\hline Mean & 44.75 & 4.35 \\
SD & 4.79 & 0.88 \\
$95 \%$ tolerance limits $(\%)$ & $100 \pm 21.39$ & $100 \pm 40.46$ \\
\hline
\end{tabular}

${ }^{1}$ The tolerance limits are given as a percentage of the mean. necessary as the relation between TBK in milliequivalents per kilogram and skinfold thickness was not linear. The transformation used was $100 \log _{10}(10 \mathrm{~S}-18)$, where $S$ is the skinfold thickness in millimeters (9).

Examination of the results suggested that at a given mean skinfold thickness the observed TBK was higher in childiren whose weight was approximately equal to their expected weight for height than in children in whom the difference was marked, i.e., in the very thin or very obese. The pradiction was improved by multiplying the mean skinfold thickness before $\log$ transformation by $1+(100-P) / 100$ where $P$ is the weight as a percentage of the expected weight for height. The predictor then becomes $100 \log _{10}\{10 \mathrm{~S}[1+(100-$ P)]/100\}-18). This is termed correction $A$ in Table 4. Prediction was further improved by altering the constants, the best prediction of TBK in milliequivalents per kilogram given by $100 \log _{10} \quad\{10 \mathrm{~S}[1.51+(100-\mathrm{P})] / 100\}-16.5$. This is termed correction $B$. The mean skinfold thickness, correction $A$ and correction $B$ are compared in Table 4 . Correction $B$ is termed the log transformation of the corrected skinfold thickness (LCS). The equation for the regression line is TBK $(\mathrm{mEq} / \mathrm{kg})=98.68-0.2912$ LCS. The tolerance limits are $100 \% \pm 6.0 \%$.

\section{PKEDICTION OF LOG TBK IN MILLIEQUIVALENTS AND MILLIEQUIVALENTS PER KILOGRAM BY FUNCTIONS OF $\mathrm{W}, \mathrm{H}$, AND $\mathrm{W} / \mathrm{H}$}

For every $f(W, H)$ the tolerance limits were narrower for the prediction of the $\log \mathrm{TBK}$ than for the prediction of TBK. The

Table 2. Prediction of total body potassium (TBK) in milliequivalents and milliequivalents per kilogram by $f(W, H)^{1}$

\begin{tabular}{ccc}
\hline $\mathrm{TBK}$ & $\mathrm{f}(\mathrm{W}, \mathrm{H})$ & $\begin{array}{c}95 \% \text { tolerance } \\
\text { limits, } \%\end{array}$ \\
\hline $\mathrm{mEq}$ & $\mathrm{W}$ & $100 \pm 19.9$ \\
$\mathrm{mEq}$ & $\mathrm{W}^{3 / 4}, \mathrm{~W}^{2} / \mathrm{H}^{3}$ & $100 \pm 18.3$ \\
$\mathrm{mEq} / \mathrm{kg}$ & $\mathrm{W} / \mathrm{H}^{2}$ & $100 \pm 18.4$ \\
$\mathrm{mEq} / \mathrm{kg}$ & $(\mathrm{W} / \mathrm{H})^{3}, \mathrm{~W}^{2} / \mathrm{H}^{3}$ & $100 \pm 18.2$ \\
\hline
\end{tabular}

1 The observed TBK is expressed as a percentage of the predicted value. W: weight; $\mathrm{H}$ : height.

Table 3. Correlation between total body potassium in milliequivalents per kilogram and log transformation (9) of skinfold thickness

\begin{tabular}{lc}
\hline Skinfold thickness & $\mathrm{r}$ \\
\hline Midtriceps & -0.889 \\
Subscapular & -0.898 \\
Paraumbilical & -0.777 \\
Mean & -0.944 \\
\hline
\end{tabular}

Table 4. Prediction of total body potassium (TBK) in milliequivalents per kilogram by functions of skinfold thickness and weight for height ${ }^{1}$

\begin{tabular}{lc}
\hline \multicolumn{1}{c}{ Skinfold } & $\begin{array}{c}95 \% \text { tolerance } \\
\text { limits, } \%\end{array}$ \\
\hline Mean & $100 \pm 7.11$ \\
Correction $A$ & $100 \pm 6.37$ \\
Correction $B$ & $100 \pm 6.18$ \\
\hline
\end{tabular}

${ }^{1}$ The observed TBK is expressed as a percentage of the predicted value. 
best single predictor of the $\log \mathrm{TBK}$ in milliequivalents was $\mathrm{W}^{1 / 4}$ and of $\log \mathrm{TBK}$ in milliequivalents per kilogram, $\mathrm{W} / \mathrm{H}^{2}$ (Table 5). When two $\mathrm{f}(\mathrm{W}, \mathrm{H})$ were used to predict the log TBK in milliequivalents per kilogram, there was no increase in the accuracy of the prediction. The $\log$ TBK in milliequivalents was more accurately predicted by $\mathrm{W} / \mathrm{H}^{2}$ and $(\mathrm{W} / \mathrm{H})^{1 / 4}$ than by $\mathrm{W}^{1 / 4}$, the tolerance limits being $100 \% \pm 3.3 \%$ and $100 \% \pm$ $3.6 \%$, respectively (Table 5 ). This multivariate prediction was the most accurate predictor of the log TBK in milliequivalents, although several other $\mathrm{f}(\mathrm{W}, \mathrm{H})$ were only marginally worse. The formula for the regression plane was $\log _{10} \mathrm{TBK}(\mathrm{mEq})=6.43$ $(\mathrm{W} / \mathrm{H})^{1 / 4}-433.30 \mathrm{~W} / \mathrm{H}^{2}-0.49$.

\section{PREDICTION OF LOG TBK IN MILLIEQUIVALENTS BY} FUNCTIONS OF $\mathrm{W}, \mathrm{H}, \mathrm{W} / \mathrm{H}$, AND SKINFOLD THICKNESS

The prediction of the $\log$ TBK in milliequivalents by two $\mathrm{f}(\mathrm{W}, \mathrm{H})$ was usually, but not invariably, improved by the inclusion of a function of skinfold thickness. The log TBK in milliequivalents was most accurately predicted by $\mathrm{W} / \mathrm{H}^{2}$, $(\mathrm{W} / \mathrm{H})^{1 / 4}$, and a $\log$ transformation of the mean skinfold thickness' (Table 6). The formula for the regression line was $\log _{10}(\mathrm{TBK}$ in $\mathrm{mEq})=6.111(\mathrm{~W} / \mathrm{H})^{1 / 4}-262.82 \mathrm{~W} / \mathrm{H}^{2}-$ 0.213 LS -0.241 where $W$ is the weight in kilograms, $H$ is the height in centimeters, LS is $\log _{10}(10 \mathrm{~S}-18), \mathrm{S}$ is the mean skinfold thickness in millime ters. The $95 \%$ tolerance limits are $100 \pm 1.3 \%$.

As was the case with the prediction of $\log$ TBK by two $\mathrm{f}(\mathrm{W}, \mathrm{H})$ there were several functions incorporating skinfold thickness which were almost as accurate as the one given above (Table 6).

The most striking feature of the prediction of $\log$ TBK in milliequivalents was the frequency with which the fourth root of weight, height, or weight over height gave the most accurate predictions. This was true for prediction by two $\mathrm{f}(\mathrm{W}, \mathrm{H})$ alone and in combination with a function of skinfold thickness. Fourteen of the 15 most accurate predictions of the log TBK in milliequivalents contained a fourth root. The cube, sixth, and eighth roots of $\mathrm{W}$ and $\mathrm{W} / \mathrm{H}$ were not investigated as extensively as the functions listed earlier. When one of these functions was substituted for the fourth root in the prediction

Table 5. Prediction of log total body potassium (TBK) in milliequivalents and milliequivalents per kilogram by $f(W, H)^{1}$

\begin{tabular}{lcc}
\hline $\log \mathrm{TBK}$ & $\mathrm{f}(\mathrm{W}, \mathrm{H})$ & $\begin{array}{c}95 \% \text { tolerance } \\
\text { limits, } \%\end{array}$ \\
\hline $\mathrm{mEq}$ & $\mathrm{W}^{1 / 4}$ & $100 \pm 3.6$ \\
$\mathrm{mEq}$ & $\mathrm{W} / \mathrm{H}^{2},(\mathrm{~W} / \mathrm{H})^{1 / 4}$ & $100 \pm 3.3$ \\
$\mathrm{mEq} / \mathrm{kg}$ & $\mathrm{W} / \mathrm{H}^{2}$ & $100 \pm 4.8$. \\
$\mathrm{mEq} / \mathrm{kg}$ & $\mathrm{W}^{2}, \mathrm{~W}^{2} / \mathrm{H}^{3}$ & $100 \pm 4.8$ \\
\hline
\end{tabular}

${ }^{1}$ The log observed TBK is expressed as a percentage of the log of the predicted value. W: weight; $\mathrm{H}$ : height.

Table 6. Prediction of $\log _{1}$ o total body potassium (TBK) in milliequivalents by functions of weight $(W)$, height $(H)$, and skinfold thickness (LS) (9)
$\mathrm{f}(\mathrm{W} / \mathrm{H})$

$(\mathrm{W} / \mathrm{H})^{1 / 4}, \mathrm{~W} / \mathrm{H}^{2} \mathrm{LS}$

$W^{1 / 4}, W, L S$

$W^{1 / 4}, W^{3 / 4}, L S$

$\mathrm{W}^{1 / 4}, \mathrm{~W}^{1 / 2}, \mathrm{LS}$

$\mathrm{H}^{1 / 4},(\mathrm{~W} / \mathrm{H})^{1 / 4}, \mathrm{LS}$

95\% tolerance limits, \%

$100 \pm 1.26$

$100 \pm 1.31$

$100 \pm 1.32$

$100 \pm 1.32$

$100 \pm 1.32$
${ }^{1} \mathrm{LS}=\log _{10}(10 \mathrm{~S}-18)$, where $\mathrm{S}$ is the mean skinfold thickness (9). of $\log$ TBK by two $f(W, H)$ the tolerance limits were not as narrow.

\section{DISCUSSION}

The mean TBK in milliequivalents per kilogram and the SD are similar to the values reported previously for normal children, and for children who have recovered from proteincalorie malnutrition (PCM) $(1,2,13,22-24)$. The prediction of the "normal" TBK of the individual being investigated can assist in the interpretation of the TBK result by decreasing the wide normal range. In nonedematous children, a function of $(\mathrm{W} / \mathrm{H})^{1 / 4}, \mathrm{~W} / \mathrm{H}^{2}$, and skinfold thickness is an accurate predictor of the $\log$ TBK in milliequivalents. The narrow $95 \%$ tolerance limits, $100 \% \pm 1.3 \%$, allow the detection of small deviations from normal.

The measurement of skinfold thickness is inaccurate in edematous patients and the TBK has to be predicted from $\mathrm{f}(\mathrm{W}, \mathrm{H})$. This is not a major disadvantage as the $95 \%$ tolerance limits for the prediction of the $\log \mathrm{TBK}$ in milliequivalents by $(\mathrm{W} / \mathrm{H})^{1 / 4}$ and $\mathrm{W} / \mathrm{H}^{2}$ are still narrow, i.e., $100 \% \pm 3.3 \%$. A potential difficulty is the overestimate of the TBK by the weight of excess fluid. Table 7 shows the effect of a $10 \%$ increase in weight on the predicted log TBK of six theoretical children. The main factor affecting the overestimate of TBK is the relationship between the actual weight and the expected weight for height. The actual height is of less importance, but the overestimate is larger in the smallest children. The TBK was overestimated by 0.7 to $0.9 \%$ in children whose weight was approximately $100 \%$ of the expected weight for height and by $1.5-1.7 \%$ when the ratio was $60 \%$. This may be of particular importance in malnourished children.

In edematous patients, and others where rapid.changes in body composition may occur, height would be the ideal predictor. Of the functions of height investigated the best correlation was between the $\log \mathrm{TBK}$ and $\mathrm{H}^{1 / 4}(\mathrm{r}=0.939)$ but compared with $(\mathrm{W} / \mathrm{H})^{1 / 4}$ and $\mathrm{W} / \mathrm{H}^{2}$ it was inaccurate. The inaccuracy introduced by the weight of the excess fluid is not large enough to invalidate the use of the latter function. The relation between TBK in milliequivalents and $\mathbf{H}, \mathbf{H}^{2}$, and $\mathrm{H}^{3}$ confirms the findings of Flynne et al. (10) and contrasts with those of Alleyne (1). Alleyne found a closer correlation with $\mathrm{H}$ than $\mathrm{H}^{3}(\mathrm{r}=0.8383$ and $\mathrm{r}=0.7827)$. In this series there was a slightly higher correlation with the $\mathrm{H}^{2}$ and $\mathrm{H}^{3}$ than with $\mathrm{H}(\mathrm{r}$ $=0.930, \mathrm{r}=0.930$, and $\mathrm{r}=0.927$, respectively). The difference is not due to the presence of normal children in this study. For the "recovered" cases of PCM the correlation coefficients were 0.862 for $\mathrm{H}, 0.864$ for $\mathrm{H}^{2}$, and 0.868 for $\overline{\mathrm{H}}^{3}$.

As the TBK is influenced by age $(4,23)$, age has to be incorporated in the predicting function, or different functions calculated for various age groups. There was no correlation between the TBK in milliequivalents per kilogram and age in the normal weight children, $(r=0.180)$, nor in all of the children $(r=0.037)$. There is no linear increase in the potassium concentration per kilogram body weight in this age group (23), contrary to Garrow's suggestion (13). This would not exclude such an increase in the potassium concentration of the fat-free body weight, as it may be masked by other changes in body composition, e.g., an increase in body fat. The lack of correlation between TBK in milliequivalents per kilogram and age is fortunate as many children in this age group are malnourished and have the body composition of far younger children (5). It would be impossible to assess the "body composition age" of such children accurately.

The prediction of TBK from measures of body composition, e.g., total body water, extracellular fluid volume, and urinary creatinine, has two main disadvantages when compared with prediction from anthropologic measurements. Firstly, the collection and analysis of specimens takes longer than the measurement of weight, height, and skinfold thickness, and may interfere with the management of the patient. Secondly, 
Table 7. Effect on predicted total body potassium ${ }^{1}$ (TBK) of $10 \%$ change in weight in six theoretical children

\begin{tabular}{ccccc}
\hline $\begin{array}{c}\text { Was \% experi- } \\
\text { mental wt for } \\
\text { H(approx.) }\end{array}$ & $\mathrm{H}, \mathrm{cm}$ & $\mathrm{W}, \mathrm{kg}$ & $\begin{array}{c}\text { Predicted } \\
\log \mathrm{TBK}\end{array}$ & $\begin{array}{c}\text { Difference, } \\
\%\end{array}$ \\
\hline \multirow{2}{*}{60} & 50 & 2.0 & 2.074 & 1.7 \\
& & 2.2 & 2.200 & \\
& 63 & 3.9 & 2.292 & 1.5 \\
& & 4.29 & 2.326 & \\
& 76 & 6.1 & 2.475 & 1.5 \\
100 & 50 & 6.71 & 2.512 & \\
& & 3.4 & 2.204 & 0.9 \\
& 63 & 6.74 & 2.224 & \\
& & 7.26 & 2.448 & 0.7 \\
& 76 & 10.2 & 2.664 & \\
& & 11.22 & 2.654 & 0.7 \\
\hline
\end{tabular}

${ }^{1}$ Predicted $\log$ TBK in milliequivalents. H: height; W: weight.

potassium losses may result in metabolic changes which affect body composition, making these predictors no more accurate than the anthropologic measurements. If the purpose of the TBK estimation is to detect a low TBK and provide a guide for treatment there is no obvious advantage in detailed laboratory investigation.

The good correlation ( $r=0.93$ ) between TBK and the log transformation of the mean skinfold thickness is not surprising as one of the principle uses of TBK determinations has been the estimation of total body fat $(11,26)$. Forbes et al. (11) reported a correlation coefficient of 0.80 for fat content calculated from the TBK and mean skinfold thickness. The difference between the correlation coefficients may be due to the log transformation, to the relatively narrow range of skinfold thickness in this study, or to small variations in the potassium content of the fat-free body weight resulting in inaccuracies in the calculated fat content.

The reason for the improvement in the correlation after correction for deviations in the ratio of weight to expected weight for height from $100 \%$ is not known. The factor may correct for a reduction in muscle bulk and/or an abnormality in muscle composition in markedly underweight children. In children who have a high expected weight for height there may be an underestimate of body fat by the skinfold thicknesses measured. Another possibility is the factor corrects for geometric losses; i.e., self-absorption losses related to the thicknesses of the tissues between the source and the detector. This possibility is not excluded by the fact that functions of weight, height, and skinfold thickness did not correlate better with counting efficiency than weight alone (18). The improvement in the correlation brought about by altering the constants may be due to differences between young and older subjects in the thickness of the dermis or in the distribution of fat. Theoretically, the intercept should approximate to the potassium content of the fat-free body weight. As the value obtained, 98.68, is higher than any of the values previously reported (25), it is likely that the relation between the TBK in milliequivalents per kilogram and the log transformation of the corrected skinfold thickness is not linear at extremely low or high values of skinfold thickness.

The sex difference found in adults is largely due to differences in body fat. It is not clear when this sex difference appears. Anderson and Langham (4) reported that it only appeared at puberty but Reba et al. (25) found a sex difference at the age of 5 years. Novak et al. $(23,24)$ found no sex difference at 1 month nor at intervals up to 1 year when expressed as TBK in milliequivalents per kilogram (23). There was no difference in the normal weight children of this series.
Novak (23) has found a good correlation between TBK and weight but the SD values show a wide range and the $95 \%$ tolerance limits of his prediction equations must be wide, and so limit their usefulness in the individual pathophysiologic state. Burkinshaw et al. (6) investigated the prediction of TBK in grams in adults by weight, lean body mass, skinfold thickness, thigh muscle width, and thigh circumference. The prediction of the TBK of adults by these functions is slightly more accurate than the prediction of TBK in milliequivalents in children using weight, height, and skinfold thickness. It is less accurate than the prediction of the log TBK by these functions or of TBK in milliequivalents per kilogram by skinfold thickness and weight as a precentage of the expected weight for height.

The accurate prediction of the normal TBK of an individual by simple anthropologic measurements enhances the clinical value of TBK determinations. Relatively small deviations from normal can be detected in edematous and nonedematous children.

\section{REFERENCES AND NOTES}

1. Alleyne, G. A. O.: Studies of total body potassium in infantile malnutrition: The relation to body fluid spaces and urinary creatinine. Clin. Sci., 34: 199 (1968).

2. Alleyne, G. A. O., Millward, D. J., and Scullard, G. H.: Total body potassium, muscle electrolytes and glycogen in malnourished children. J. Pediat., 76: 75 (1970).

3. Alleyne, G. A. O.: Studies on total body potassium in malnourished infants. Factors affecting potassium repletion. Brit. J. Nutr., 24: 205 (1970).

4. Anderson, E. C., and Langham, W. H.: Average potassium concentration of the human body as a function of age. Science, 130: 713 (1959).

5. Brock, J. F., and Hansen, J. D. L.: Body composition and appraisal of nutrition. Symposia of the Society for the Study of Human Biology Volume VI Human Body Composition: Approaches and Applications, p. 245 (Pergamon Press, Oxford, 1956).

6. Burkinshaw, L., Cotes, J. E., Jones, P. R. M., and Knibbs, A. V.: Prediction of total body potassium from anthropometric measurements. Human Biol., 43: 344 (1971).

7. Cohn, S. H., and Dumbrowski, C. S.: Absolute measurement of whole-body potassium by gamma-ray spectrometry. J. Nucl. Med., 11: 239 (1970).

8. Donath, A., Poretti, G., and Zuppinger, A.: Abstracts of the European Society for Paediatric Research, p. 18 (1970).

9. Edwards, D. A. W., Hammond, W. H., Healy, M. J. R., Tanner, J. M., and Whitehouse, R. H.: Design and accuracy of calipers for measuring subcutaneous tissue thickness. Brit. J. Nutr., 9: 133 (1955).

10. Flynne, M. A., Woodruff, C., Clark, J., and Chase, G.: Total body potassium in normal children. Pediat. Res., 6: 239 (1972).

11. Forbes, G. B., Gallup, J., and Hursch, J. B.: Estimation of total body fat from potassium-40 content. Science, 133: 101 (1960).

12. Garrow, J. S.: The use and calibration of a small body counter for the measurement of total body potassium in malnourished infants. W. Indian Med. J., XIV: 73 (1965).

13. Garrow, J. S.: Total body potassium in kwashiorkor and marasmus. Lancet, ii: 455 (1965).

14. Hansen, J. D. L., Schendal, H. E., Wilkins, J. A., and Brock, J. F.: Nitrogen metabolism in children with kwashiorkor receiving milk and vegetable diets. Pediatrics, 25: 258 (1960).

15. Hughes, D., and Williams, R. E.: The calibration of a whole-body radioactivity counter for the measurement of body potassium content in clinical studies. Clin. Sci., 32: 495 (1967).

16. Jelliffe, D. B.: The assessment of the nutritional status of the community, p. 221 (World Health Organization, Geneva, 1966).

17. Loevinger, R., and Berman, M.: Efficiency criteria in radioactivity counting. Nucleonics, 9: 26 (1951).

18. Mann, M. D.: Ph.D. thesis, University of Cape Town, 1972.

19. Mann, M. D., and Hansen, J. D. L.: The interpretation of total body potassium results in young children. Potassium supplement to the S. Afr. Med. J., 46: 37 (1972).

20. Miller, R.: Simultaneous Statistical Inference, p. 109 (McGraw-Hill, New York, 1966).

21. Monckeberg, F.: In: R. A. McCance and E. M. Widdowson: Calorie Deficiencies and Protein Deficiencies, p. 91 (Churchill, London, 1968).

22. Nichols, B. L., Alleyne, G. A. O., Barnes, D. J., and Hazlewood, C. F.: Relationship between muscle potassium and total body potassium in infants with malnutrition. J. Pediat., 74: 49 (1969).

23. Novak, L. P.: Total body potassium during the first year of life determined by whole body counting of ${ }^{40}$ K. J. Nucl. Med., 14: 550 (1973). 
24. Novak, L. P., Hamamoto, K., Orvis, A. L., and Burke, E. C.: Total body potassium in infants. Amer. J. Dis. Child . 119: 419 (1970).

25. Reba, R. C., Cheek, D. B., and Leitnaker, F. C.: Human growth. In: D. B. Cheek: Body Composition, Cell Growth, Energy and Intelligence, p. 165. (Lea \& Febiger, Philadelphia, 1968).

26. Remenchik, A. P., Miller, C. E., and Kessler, W. V.: Estimates of body composition derived from potassium measurements. United States Atomic Energy Commission, Argonne National Laboratory, 73: 231 (1968).

27. Snedecor, G. W., and Cochran, W. G.: Statistical Methods, Ed. 6, pp. 172, 381 (Iowa State University Press, Ames, Iowa, 1967).

28. Tyson, I., Genna, S., Jones, R. L., Bikerman, V., and Burrows, B. A.: Body potassium measurements with a total body counter. J. Nucl. Med., 11: 255 (1970).

29. Waterlow, J. C.: Classification and definition of protein-calorie malnutrition. Brit. Med. J., 3: 566 (1972).

30. Waterlow, J. C., and Alleyne, G. A. O. Protein malnutrition in children: Advances in knowledge in the last ten years. Advan. Protein Chem., 25: 117 (1971).
31. Wolfson, W. Q., Cohn, C., Calvary, E., and Ichaba, F.: Studies in serum proteins $V$. A rapid procedure for the estimation of total protein, true albumin, total globulin, alpha globulin, beta globulin and gamma globulin in $1.0 \mathrm{ml}$ of serum. Amer. J. Clin. Pathol., 18: 723 (1948).

32. Financial assistance was received from the Cape Provincial Administration, the South African Atomic Energy Board and National Institutes of Health Public Health Service Grant no. AMO-3995.

33. The investigations were approved by the Screening Committee of National Institutes of Health Public Health Service Grant no. AMO-3995. The nature of the procedure and the purpose of the study were explained to the mothers of the children and children were studied only after informed consent was obtained.

34. Requests for reprints should be addressed to: M. D. Bowie, M.D., Department of Paediatrics and Child Health, Medical School, University of Cape Town, Observatory, Cape, South Africa. 35. Accepted for publication July 5, 1974.
Amino acids anaerobiosis intestine

\title{
Metabolic Properties of Neonatal Transport
}

\author{
L. D. FERDINANDUS AND J. F. FITZGERALD(45) \\ Department of Pediatrics, Indiana University School of Medicine, Indianapolis, Indiana, USA
}

S. REISER

Carbohydrate Laboratory, Nutritional Institute, Department of Agriculture, Beltsville, Maryland, USA

\section{Extract}

The metabolic properties of the increased rate of transport in the 2-day-old rat intestine as compared with adult rat intestine were investigated. The intracellular accumulation of 1 mM of a prototype neutral amino acid (L-leucine) and sugar (D-galactose) was measured at $5 \mathrm{~min}$ in the presence of inhibitors and after preincubation with inhibitors. The intestine of the 2-day-old rat was found to be similar to adult rat intestine in its response to $\mathrm{Na}^{+}$dependence, sulfhydryl binders, and metabolic inhibitors under conditions of aerobiosis; however, the immature rat intestine exhibited an ability to actively accumulate amino acids to a much greater extent than adult tissue under anaerobic conditions. Transport was inhibited only $12 \%$ in the newborn intestine while adult intestine showed a $44 \%$ inhibition at initial velocities. This anaerobic transport was similarly $\mathrm{Na}^{+}$dependent and sensitive to metabolic inhibitors.

These results indicate that the increased transport found in newborn animals may be partially energized by anerobic metabolism, but suggest that the requirement for the maintenance of an active influx of sodium is similar in both neonates and adults.

\section{Speculation}

Anaerobic metabolism may partially account for the increased transport in newborn rats. Future studies may reveal whether the rate of anaerobic transport decreases in a pattern similar to the overall decrease in transport observed in the neonatal rat with maturation.

Intestinal transport has been observed to be maximal for both amino acids $(10,16,22,26)$ and sugars (9) immediately after birth. The decreased accumulation of neutral amino acids in adult rat small intestine appears to be due to the disappearance of transport sites found in the small intestine of newborn rats, rather than the presence in young animals of structurally modified transport carriers with a more efficient binding capacity $(6,26)$. It has been demonstrated that the active transport of amino acids (22) in chick small intestine soon after hatching was not completely dependent on aerobic metabolism. Measurements of glycolysis in chicken (22) and rabbit (37) small intestine have shown a decrease in the rate of anaerobic glycolysis during the first week after birth. Kidney slices from newborn rats have been shown to achieve a higher net uptake of amino acids than mature tissue after prolonged incubation $(3,4,33,35)$. Baerlocher et al. (5) have demonstrated an adaptive advantage in the presence of anoxia held by immature kidney over mature tissue. Therefore, it would be of primary physiologic interest to determine whether the increased rate of active intestinal transport in the newborn rat is energized by a specialized mechanism.

In continuing our study of transport in the 2-day-old rat 